\title{
Pengaruh Kemampuan Verbal dan Kemampuan Numerik Terhadap Kemampuan Menyelesaikan Soal Sistem Persamaan Linear Bentuk Cerita
}

\author{
Median Aulia Azmi ${ }^{*}$, Nyoman Sridana ${ }^{2}$, Arjudin ${ }^{2}$, Baidowi $^{2}$ \\ ${ }^{1}$ Mahasiswa Pendidikan Matematika, FKIP, Universitas Mataram, Mataram \\ 2 Pendidikan Matematika, FKIP, Universitas Mataram, Mataram \\ azmim0134@gmail.com
}

Diterima: 16-12-2021; Direvisi: 30-12-2021; Dipublikasi: 30-12-2021

\begin{abstract}
This study aims to determine the effect of verbal ability and numerical ability, the effect of verbal ability, and the effect of numerical ability on the ability of solving linear equation system problems. This study is an ex post facto research. The population of this study were students of class XI SMAN 9 Mataram. The sample in this study were 28 students of class XI SMAN 9 Mataram represented by four students in each class. The data analysis used is multiple linear regression analysis and simple linear regression analysis. From the results of the data analysis, there is a significant influence between verbal ability and numerical ability on the ability to solve linear equation system problems with a value of Fhitung $=3,660>$ Ftabel $=3,39$. The magnitude of this influence is written in the form of a regression equation, namely $Y=24,602+0,140 X_{1}+$ $0,224 X_{2}$. This regression equation shows that if the verbal ability score increases by 1 with a fixed numerical ability score, then the ability to solve math problems will increase by 0,140 ; and if the numerical ability score increases by 1 with a fixed verbal ability score, the value of the ability to solve story questions will increase by 0,225 and plus 24,602 from other factors.
\end{abstract}

Keywords: verbal ability; numerical ability; ability of solving linear equation system problems

\begin{abstract}
Abstrak
Penelitian ini bertujuan untuk mengetahui pengaruh kemampuan verbal dan kemampuan numerik, kemampuan verbal, dan kemampuan numerik terhadap kemampuan menyelesaikan soal sistem persamaan linear bentuk cerita. Penelitian ini merupakan penelitian ex post facto. Populasi dari penelitian ini adalah siswa kelas XI SMAN 9 Mataram. Sampel dalam penelitian ini adalah siswa kelas XI SMAN 9 Mataram berjumlah 28 orang yang diwakilkan oleh empat orang siswa disetiap kelas. Analisis data yang digunakan adalah analisis regresi linear ganda dan analisis regresi linear sederhana. Dari hasil analisis data terdapat pengaruh yang signifikan antara kemampuan verbal dan kemampuan numerik terhadap kemampuan menyelesaikan soal sistem persamaan linear bentuk cerita dengan nilai Fhitung =3,660 $>$ Ftabel $=3,39$. Besarnya pengaruh ini dituliskan dalam bentuk persamaan regresi, yaitu $=24,602+0,140 X_{1}+0,224 X_{2}$. Persamaan regresi ini menunjukkan apabila kemampuan verbal dan kemampuan numerik bertambah 1 skor maka nilai kemampuan menyelesaikan soal matematika akan bertambah 0,140 dari kemampuan verbal ditambah dengan 0,224 dari kemampuan numerik dan ditambah 24,602 dari faktor lain.
\end{abstract}

Kata Kunci: kemampuan verbal; kemampuan numerik; kemampuan menyelesaikan soal sistem persamaan linear

\section{PENDAHULUAN}

Pendidikan senantiasa menjadi perhatian utama dan pertama dalam rangka memajukan kehidupan dari generasi ke generasi sejalan dengan tuntutan kemajuan masyarakat itu sendiri. Oleh karena itu, manusia membutuhkan pendidikan dalam kehidupannya. 
Dengan adanya pendidikan, dapat membantu manusia menjadi berkembang ke arah yang lebih baik menuju suatu kemajuan.

Keberhasilan proses belajar peserta didik dapat dilihat dari keberhasilan peserta didik dalam mengerjakan soal-soal yang diberikan oleh pendidik. Keberhasilan peserta didik dalam mengerjakan soal-soal tergantung dengan tingkat kecerdasan peserta didik. Kecerdasan/inteligensi merupakan salah satu faktor yang mempengaruhi belajar peserta didik. Tingkat inteligensi besar pengaruhnya terhadap kemajuan belajar. Peserta didik yang memiliki tingkat inteligensi tinggi akan lebih berhasil daripada yang mempunyai tingkat inteligensi rendah. Namun peserta didik yang memiliki tingkat inteligensi tinggi belum pasti berhasil dalam belajarnya. Belajar adalah suatu proses yang kompleks dengan banyak faktor yang mempengaruhi, sedangkan inteligensi adalah salah satu faktor di antara faktor-faktor lain yang mempengaruhi proses belajar (Slameto, 2015).

Berdasarkan observasi yang peneliti lakukan selama Program Pengalaman Lapangan (PPL) di kelas XI SMAN 9 Mataram. Dalam proses pembelajaran matematika di sekolah terjadi komunikasi antara guru dan siswa, dalam berkomunikasi guru harus dapat memberikan penjelasan tentang materi pelajaran dengan menggunakan bahasa yang komunikatif. Apabila bahasa yang digunakan oleh guru dalam menjelaskan materi kurang komunikatif maka akan menimbulkan kesulitan bagi siswa dalam menguasai materi pelajaran yang disampaikan. Berdasarkan hasil wawancara yang dilakukan dengan salah satu guru mata pelajaran matematika SMAN 9 Mataram, banyak permasalahan dalam pembelajaran matematika salah satunya, siswa yang kesulitan dalam menerjemahkan maksud dari soal yang diberikan khususnya pada soal yang berbentuk cerita. Keadaan ini dapat mengakibatkan hasil belajar matematika siswa menjadi rendah.

Kemampuan verbal dan kemampuan numerik merupakan faktor yang dimiliki siswa sebagai potensi yang turut mempengaruhi prestasi belajar matematika siswa kelas XI SMAN 9 Matara. Hal tersebut sesuai dengan yang dikemukakan oleh Enggen dan Khauchak kemampuan verbal dan kemampuan numerik merupakan dua dari tiga komponen intelegensi ialah (1) kemampuan verbal, (2) kemampuan numerikal, (3) penalaran abstrak. Ketiga komponen ini yang mempengaruhi pencapaian prestasi belajar (Efendi, 2004). Dalam pembelajaran matematika khususnya dalam mengkaji soal cerita, kemampuan verbal dan kemampuan numerik berperan penting sebab hal tersebut adalah kemampuan dasar yang harus dimiliki siswa. Kemapuan verbal yang memadai sangat diperlukan oleh siswa kelas XI SMAN 9 Mataram agar lebih memudahkan dalam memahami dan menyelesaikan soal cerita sebab dengan kemampuan verbal yang tinggi seseorang dapat mengerti ide serta konsep dan juga dapat dengan mudah berpikir dan memecahkan masalah (Wahyudin, 2016).

Berdasarkan uraian di atas, peneliti terdorong untuk mengkaji lebih dalam untuk melakukan penelitian yang berjudul "Pengaruh Kemampuan Verbal dan Kemampuan 
Numerik Terhadap Kemampuan Menyelesaikan Soal Sistem Persamaan Linear Bentuk Cerita Siswa kelas XI SMAN 9 MATARAM Tahun Ajaran 2019/2020”.

\section{METODE PENELITIAN}

Jenis penelitian yang digunakan adalah kuantitatif. Variabel bebas dalam penelitian ini adalah kemampuan verbal $\left(X_{1}\right)$ dan kemampuan numerik $\left(X_{2}\right)$, sedangkan variabel terikat adalah kemampuan menyelesaikan soal matematika $(Y)$. Populasi dalam penelitian ini yaitu seluruh siswa kelas XI SMA Negeri 9 Mataram, terbagi menjadi 7 kelas (XI-A,XI-B, XI-C, XI-D, XI-E, XI-F, dan XI-G ) yang berjumlah 219 siswa. Teknik sampling yang digunakan adalah cluster random sampling (sampel acak cluster). Dengan sampel yang terpilih adalah semua kelas XI dengan 4(empat) pada masing-masing kelas yang berjumlah 28 siswa.

Kemampuan verbal dan kemampuan numerik diukur menggunakan tes berbentuk pilihan ganda, dan kemampuan menyelesaikan soal matematika diukur menggunakan tes essay materi materi SPL (Sistem Persamaan). Dengan indikator kemampuan verbal yang digunakan yaitu penalaran analogi, dan penalaran analitis. Untuk kemampuan numerik dengan indikator yaitu mampu melakukan penjumlahan, mampu melakukan pengurangan, mampu melakukan perkalian, mampu melakukan pembagian, mampu melakukan perhitungan sederhana matematika dan, mampu melakukan perhitungan aritmatika dasar. Kemudian untuk kemampuan menyelesaikan soal dengan indikator Keterampilan memahami masalah, keterampilan merencanakan pemecahan masalah, keterampilan menjalankan rencana, dan keterampilan memeriksa kembali.

Teknik analisis data yang digunakan adalah analisis statistik deskriptif yang digunakan untuk menganalisa data dengan cara mendeskripsikan atau menggambarkan data yang telah terkumpul sebagai mana adanya tanpa bermaksud dengan kesimpulan yang berlaku untuk umum atau generalisasi (Sugiyono, 2002)., dan analisis statistic inferensial, yaitu menggunakan regresi linear sederhana dan regresi linear berganda. Regresi linear sederhana digunakan untuk menguji pengaruh kemampuan verbal siswa terhadap kemampuan menyelesaikan soal matematika dan untuk menguji pengaruh kemampuan numeric siswa terhadap kemampuan menyelesaikan soal matematika, demgan menggunakan Uji F dan Uji t. Regresi linear berganda digunakan untuk menguji pengaruh kemampuan verbal dan kemampuan numerik siswa terhadap kemampuan menyelesaikan soal matematika dengan menggunakan Uji F.

\section{HASIL DAN PEMBAHASAN}

Berdasarkan hasil penelitian yang dilakukan dengan jumlah responden sebanyak 28 orang siswa diperoleh deskripsi secara umum sebagai berikut. 
Tabel 1. Tabel Penentuan Kategori Kemampuan Verbal

\begin{tabular}{ccc}
\hline Rentang & Kriteria & $f$ \\
\hline $12,05 \leq \bar{x}_{1}<16$ & Sangat baik & 0 \\
\hline $9,35 \leq \bar{x}_{1}<12,05$ & Baik & 9 \\
\hline $6,65 \leq \bar{x}_{1}<9,35$ & Sedang & 19 \\
\hline $3,95 \leq \bar{x}_{1}<6,65$ & Rendah & 0 \\
\hline $0,0 \leq \bar{x}_{1}<3,95$ & Sangat rendah & 0 \\
\hline
\end{tabular}

Berdasarkan hasil perhitungan diperoleh rata-rata nilai untuk tes kemampuan verbal adalah 57,25; standar deviasi 9,172; nilai minimum 44 dan nilai maksimum 75 . Dengan membandingkan nilai rata-rata tersebut ke dalam tabel di atas terlihat bahwa kualitas kemampuan verbal siswa termasuk dalam kategori sedang.

Tabel 2. Tabel Penentuan Kategori Kemampuan Numerik

\begin{tabular}{ccc}
\hline Rentang & Kriteria & $f$ \\
\hline $13,5 \leq \bar{x}_{2}<18$ & Sangat baik & 7 \\
\hline $10,5 \leq \bar{x}_{2}<13,5$ & Baik & 10 \\
\hline $7,5 \leq \bar{x}_{2}<10,5$ & Sedang & 9 \\
\hline $4,5 \leq \bar{x}_{2}<7,5$ & Rendah & 2 \\
\hline $0,0 \leq \bar{x}_{2}<4,5$ & Sangat rendah & 0 \\
\hline
\end{tabular}

Berdasarkan hasil perhitungan diperoleh rata-rata nilai untuk tes kemampuan numerik adalah 63,68; standar deviasi 14,35; nilai minimum 39 dan nilai maksimum 83 Dengan membandingkan nilai rata-rata tersebut ke dalam tabel di atas terlihat bahwa kualitas kemampuan numerik siswa termasuk dalam kategori baik.

Tabel 3. Tabel Penentuan Kategori Kemampuan Menyelesaika Soal

\begin{tabular}{ccc}
\hline Rentang & Kriteria & $F$ \\
\hline $23,95 \leq \bar{Y}<32$ & Sangat baik & 0 \\
\hline $18,65 \leq \bar{Y}<23,95$ & Baik & 2 \\
\hline $13,35 \leq \bar{Y}<18,65$ & Sedang & 20 \\
\hline $8,05 \leq \bar{Y}<13,35$ & Rendah & 6 \\
\hline $0,0 \leq \bar{Y}<8,05$ & Sangat rendah & 0 \\
\hline
\end{tabular}

Berdasarkan hasil perhitungan diperoleh rata-rata nilai untuk tes kemampuan menyelesaikan soal matematika adalah 46,89; standar deviasi 22,36; nilai minimum 31 dan nilai maksimum 63. Dengan membandingkan nilai rata-rata tersebut ke dalam tabel di atas terlihat bahwa kualitas kemampuan menyelesaikan soal matematika siswa termasuk dalam kategori sedang.

Hasil analisis regresi linear berganda dan regresi linear sederhana dengan uji t, uji F dan persamaan regresi pengaruh kemampuan verbal dan kemampuan numerik terhadap kemampuan menyelesaikan soal matematika ditampilkan pada Tabel 4, 5 dan 6 berikut. 
Tabel 4. Hasil analisis regresi linear berganda dan regresi linear sederhana dengan uji t

\begin{tabular}{lccc}
\hline \multicolumn{1}{c}{ Variabel } & Fhitung & Ftabel & Kriteria pengujian \\
\hline Kemampuan Verbal $\left(X_{1}\right)$ dan & 3,66 & 3,36 & \\
Kemampuan Numerik $\left(X_{2}\right)$ Terhadap & & & \\
Kemampuan Menyelesaikan Soal & & & \\
Matematika $(Y)$ & & & \\
\hline
\end{tabular}

Tabel 5. Hasil analisis regresi linear berganda dan regresi linear sederhana dengan uji $\mathrm{F}$

\begin{tabular}{lccc}
\hline Variabel & Fhitung & Ftabel & Kriteria pengujian \\
\hline Kemampuan Verbal $\left(X_{1}\right)$ Terhadap & 2,695 & 4,23 & \\
Kemampuan menyelesaikan Soal & & & \\
Matematika $(Y)$ & & & \\
\hline
\end{tabular}

Tabel 6. Persamaan regresi pengaruh kemampuan verbal dan kemampuan numerik terhadap kemampuan menyelesaikan soal matematika

\begin{tabular}{lccc}
\hline Variabel & Fhitung & Ftabel & Kriteria pengujian \\
\hline Kemampuan Numerik $\left(X_{2}\right)$ Terhadap & 6,772 & 4,23 & \\
Kemampuan Menyelesaikan Soal & & & \\
Matematika $(Y)$ & & & \\
\hline
\end{tabular}

Berdasarkan hasil dari analisis deskriptif kemampuan verbal siswa kelas XI, didapatkan rata-rata nilai kategori kemampuan verbal siswa adalah 57,25 dengan kriteria sedang, dengan nilai minimum 44 dan nilai maksimum 75, selanjutnya rata-rata nilai kategori kemampuan numerik siswa adalah 63,68 dengan kriteria baik, dengan nilai minimum 39 dan nilai maksimum 83, dan untuk kemampuan menyelesaikan soal SPL bentuk cerita didapatkan rata-rata nilai 46,89 dengan kriteria sedang, dengan nilai minimum 31 dan nilai maksimum 63.

Setelah dilakukan analisis statistik deskriptif untuk melihat kemampuan sampel secara umum selanjutnya peneliti menguji hasil jawaban siswa dengan analisis statistik inferensial untuk melihat pengaruh variabel bebas yang diteliti terhadap variabel terikat menggunakan uji regresi berganda dan uji regresi sederhana. Untuk melihat pengaruh kemampuan verbal dan kemampuan numerik terhadap kemampuan menyelesaikan soal SPL bentuk cerita diperoleh nilai Fhitung $=3,660>$ Ftabel $=3,39$. Oleh karena itu, $H_{0}$ di tolak, maka ada pengaruh yang signifikan antara kemampuan verbal dan kemampuan numerik terhadap kemampuan menyelesaikan soal SPL bentuk cerita. Besarnya pengaruh ini dituliskan dalam bentuk persamaan regresi, yaitu $Y=24,602+0,140 X_{1}+$ $0,224 X_{2}$. Persamaan regresi ini menunjukkan apabila kemampuan verbal dan kemampuan numerik bertambah 1 skor maka nilai kemampuan menyelesaikan soal matematika akan bertambah 0,140 dari kemampuan verbal ditambah dengan 0,224 dari kemampuan numerik dan ditambah 24,602 dari faktor lain.

Besarnya pengaruh kemampuan verbal dan kemampuan numerik terhadap kemampuan menyelesaikan soal cerita dapat dilihat nilai $R^{2}=0,226=22,6 \%$. Maksud dari angka tersebut yaitu besarnya pengaruh kemampuan verbal dan kemampuan numerik terhadap kemampuan menyelesaikan soal matematika adalah $22,6 \%$ dan sisanya 
dipengaruhi oleh faktor lain. Hal ini sejalan dengan hasil penelitian Zuhriyah (2013) dan Hardiani (2014) yang menyatakan bahwa ada pengaruh yang positif dan signifikan kemampuan verbal dan kemampuan numerik secara bersama-sama, karena ketika siswa mempunyai kemampuan verbal dan kemampuan numerik yang tinggi, maka kemampuan menyelesaikan soal cerita matematika siswa juga tinggi.

Selanjutnya untuk mengetahui pengaruh kemampuan verbal terhadap kemampuan menyelesaikan soal matematika, digunakan regresi linear sederhana dengan uji $F$ diperoleh Fhitung $=2,695<$ Ftabel $=4,23$ yang berarti tidak ada pengaruh yang signifikan antara kemampuan verbal terhadap kemampuan menyelesaikan soal cerita matematika siswa. Hasil ini tidak sejalan dengan pendapat Nurhadi (2010) dan Manullang (2003), yang menemukan bahwa penguasaan verbal mempunyai pengaruh yang sangat berarti terhadap penguasaan matematika.

Kemudian untuk pengaruh kemampuan numerik terhadap kemampuan menyelesaikan soal cerita matematika, digunakan juga analisis regresi linear sederhana dengan uji $F$ diperoleh Fhitung $=6,772>$ Ftabel $=4,23$. Besarnya pengaruh ini dituliskan dalam bentuk persamaan regresi, yaitu $Y=30,447+0,258 X_{2}$. Persamaan regresi ini menunjukkan apabila nilai kemampuan numeric bertambah 1 skor maka kemampuan menyelesaikan soal cerita matematika akan bertambah sebesar 0,258. Besarnya pengaruh kemampuan numerik terhadap kemampuan menyelesaikan soal cerita matematika dapat dilihat dari nilai yaitu $R^{2}=0,205=20,5 \%$. Maksud dari angka tersebut yaitu pengaruh kemampuan numerik terhadap kemampuan menyelesaikan soal matematika adalah 20,5\% dan sisanya dipengaruhi oleh faktor lain. Hal ini sesuai dengan penelitian Midah (2018), yang mengemukakan bahwa kemampuan numerik mempengaruhi hasil belajar matematika siswa dimana semakin baik kemampuan numerik siswa maka hasil belajar matematikanya semakin tinggi.

Berdasarkan hasil pengamatan dalam penelitian ini, masih terdapat faktor lain yang menjadi penyebab kemungkinan hasil yang berbeda dengan penelitian yang lain, yaitu dalam pelaksanaan tes utamanya pemberian tes hasil belajar matematika tidak menutup kemungkinan terdapat kerjasama diantara siswa mengingat bentuk tes yang diberikan adalah tes objektif, walaupun pengawasan yang dilakukan seketat mungkin. Kemudian tidak dapat dihindari adanya siswa menjawab tes yang diberikan dengan cara menebak jawaban. Dengan demikian kemampuan guru untuk menerapkan metode mengajar yang relevan dengan usaha mengembangkan verbal siswa sangat diperlukan.

\section{SIMPULAN}

Terdapat pengaruh yang signifikan antara kemampuan verbal dan kemampuan numerik terhadap kemampuan menyelesaikan soal sistem persamaan linear bentuk cerita dengan nilai Fhitung $=3,660>$ Ftabel $=3,39$. Besarnya pengaruh ini dituliskan dalam bentuk persamaan regresi, yaitu $Y=24,602+0,140 X_{1}+0,224 X_{2}$. Persamaan regresi ini menunjukkan apabila kemampuan verbal dan kemampuan numerik bertambah 1 skor maka nilai kemampuan menyelesaikan soal matematika akan bertambah 0,140 dari 
kemampuan verbal ditambah dengan 0,224 dari kemampuan numerik dan ditambah 24,602 dari faktor lain.

\section{REFERENSI}

Efendi, K. (2004). Hubungan antara konsep diri dan kemampuan verbal dengan prestasi belajar pada siswa kelas lima Sekolah Dasar Muhammadiyah Sukonandi Yogyakarta. Humanitas Indonesian Psychological Journal. 1(1): 26-31. http://dx.doi.org/10.26555/humanitas.v1i1.20310

Hardiani, N. (2014). Pengaruh kemampuan verbal dan numerik terhadap kemampuan menyelesaikan soal cerita sistem persamaan linier. Beta: Jurnal Tadris Matematika, 7(1), 64-71. Retrieved from http://jurnalbeta.ac.id/index.php/betaJTM/article/view/44

Manullang, M. (2003). Pengaruh penguasaan numerik dan penguasaan verbal terhadap prestasi belajar matematika. Jurnal Ilmu Pendidikan, 10(2): 162-173.

Midah. (2018). Korelasi antara kemampuan numerik dengan prestasi belajar matematika siswa di SMP Muhammadiyah 4 Banjarmasin Tahun Pelajaran 2017/2018. Skripsi tidak diterbitkan.

Nurhadi. (2010). Membaca cepat dan efektif. Bandung Sinar baru Algesindo.

Slameto. (2005). Evaluasi pendidikan. Jakarta: Bumi Aksara.

Sugiyono. (2016). Metode penelitian pendidikan. Bandung: CV. Alfabeta.

Wahyuddin. (2016). Analisis kemampuan menyelesaikan soal cerita matematika ditinjau dari kemampuan verbal. Beta: Jurnal Tadris Matematika, 9(2): 148-160. http://dx.doi.org/10.20414/BETAJTM.V9I2.9

Zuhriyah, A. (2013). Pengaruh Kemampuan Verbal dan Kemampuan Numerik Terhadap Prestasi Belajar Matematika Siswa Kelas VIII C SMP Zainuddin Waru Sidoarjo. Skripsi tidak diterbitkan. 